\title{
Losses of water, soil, and nutrients during high-intensity simulated rainfall in two soil management systems different sources of fertilization
}

\author{
Alexandra Minossi de $\operatorname{Lemos}^{1}$ (D) Elemar Antonino Cassol ${ }^{2}($ i) \\ Cláudia Alessandra Peixoto de Barros $^{2 *} \mathbb{C}$
}

${ }^{1}$ Engenheiros e Economistas Consultores (ENECON S. A), Porto Alegre, RS, Brasil.

${ }^{2}$ Departamento de Solos, Faculdade de Agronomia, Universidade Federal do Rio Grande do Sul (UFRGS) 91540-000, Porto Alegre, RS, Brasil. E-mail: claudia.barros@ufrgs.br. "Corresponding author.

\begin{abstract}
The goal of this study was to quantify the water, soil, and soluble nutrient losses during high-intensity rainfall simulated in two soil preparation systems with four sources of fertilization. Forty-five days after the corn seeding, a $120 \mathrm{~mm} \mathrm{~h}^{-1}$ intensity rainfall was simulated during 90 min in field plots with conventional tillage (CT) or no-tillage (NT). Each system had four repetitions with the fertilizer treatments, including without fertilization, mineral, urban waste compost (UWC), and pig slurry. $P, K, C a$, and $K$ concentrations were measured in soluble form, in addition to electrical conductivity, $\mathrm{pH}$, water, and soil losses. As expected, the greatest soil losses occurred with CT; however, the greatest water losses occurred with NT. Among the fertilizers, UWC was more efficient because it had the highest infiltration rates. The concentrations of $\mathrm{P}, \mathrm{K}, \mathrm{Ca}$, and $\mathrm{Mg}$ did not exhibit any interaction between fertilization and soil tillage treatments. $K$ was the nutrient that presented the greatest losses $\left(\mathrm{kg} \mathrm{ha}^{-1}\right)$ at the end of the simulated rainfall because of the highest concentrations (mg $\left.L^{-1}\right)$ added to high runoff coefficients of $45 \%$ for CT and 77\% for NT. Thus, the evaluated system with cover crops and minimum soil tillage was not sufficient to control nutrient transfer in the soluble form during intense rainfall events.

Key words: fertilisers, runoff, extreme rainfall event, water pollution.
\end{abstract}

Perdas de água, solo e nutrientes durante chuva simulada de alta intensidade, em dois sistemas de manejo do solo e diferentes fontes de adubação

RESUMO: O objetivo do trabalho foi quantificar as perdas de água, solo e nutrientes na forma solúvel durante chuva simulada de alta intensidade, em dois sistemas de preparos do solo e quatro fontes de adubação. Quarenta e cinco dias após a semeadura do milho, uma chuva com intensidade de $120 \mathrm{~mm} \mathrm{~h}^{-1}$ foi simulada durante 90 minutos, em parcelas de campo sob preparo convencional (PC) e plantio direto (PD). Em cada preparo há quatro repetições dos tratamentos com adubação: sem fertilização, mineral, composto de lixo urbano (CO), e dejetos de suíno. Foram mensuradas as concentrações de $\mathrm{P}, \mathrm{K}, \mathrm{Ca}, \mathrm{Mg}$ na forma solúvel, além da condutividade elétrica - Ce, pH, perda de água e solo. Conforme esperado as maiores perdas de solo ocorreram para o PC, entretanto, as maiores perdas de água no PD. Entre as adubações, o CO foi o mais eficiente, pois apresentou as maiores taxas de infiltração. As concentrações de $P, K, C a$ e $M g$ não apresentaram interação entre os tratamentos de adubação e os tratamentos de preparo do solo. $O \mathrm{~K}$ foi o nutriente que apresentou as maiores perdas $\left(\mathrm{kg}\right.$ ha ${ }^{-1}$ ) ao final da chuva simulada, devido as maiores concentrações $\left(\mathrm{mg} \mathrm{L}^{-1}\right)$ somado aos altos coeficientes de escoamento superficial sendo $45 \%$ para o preparo convencional e 77\% para o plantio direto. Ao final, o sistema avaliado com plantas de cobertura e mínimo revolvimento do solo não foi suficiente para controlar a transferência de nutrientes na forma solúvel durantes eventos de chuvas intensas.

Palavras chave: fertilizantes, escoamento superficial, evento extremo, poluição das águas.

\section{INTRODUCTION}

Contamination and pollution of rivers by animal waste and chemical fertilizers are some of the main consequences of water erosion (QUINTON et al., 2010). In addition to the effects at the site of the loss of soil nutrients, there are relevant environmental and socioeconomic consequences (DECHEN et al., 2015). The magnitude of the erosive process and runoff generation may intensify the transfer of soil chemical elements to rivers. Studies have shown that an increase in the occurrence of extreme rainfall events acts directly on these processes through high rainfall intensities and volumes (OBREGÓN; MARENGO, 2007). 
Monitoring programs in Brazil are based on measurements of flows, sediments, and waterquality parameters. However, collections occur during predetermined periods, which may or may not consider rainfall events and rarely occur during extreme events (MARTÍNEZ-CARRERAS et al., 2012). Simulated plot-scale rainfall testing is an alternative for assessing the potential for the transfer of water, sediment, and chemical elements, such as nutrients, metals, and geochemicals (NIE et al., 2014; SARKAR et al., 2015) from the soil to rivers.

Additionally, recent literature results showed that conservationist systems, such as the notillage system, fall short of what is expected when complementary practices, such as terraces, are not used when necessary (LONDERO et al., 2018). Loss of water and nutrients in their soluble form by runoff may not be reduced by the presence of cover plants and minimum soil disturbance (DEUSCHLE et al., 2019; GONZALEZ, 2018).

The goal of this study was to quantify the losses of water, soil, and nutrients in their soluble form during high-intensity simulated rainfall testing.

\section{MATERIALS AND METHODS}

\section{Study site}

The study was conducted at the Experimental Agronomic Station of the Federal University of Rio Grande do Sul (UFRGS), located in the municipality of Eldorado do Sul - RS - BR $\left(30^{\circ} 05^{\prime} \mathrm{S}, 51^{\circ} 40^{\prime} \mathrm{W}\right)$ and an average altitude of 42 masl. The climate is classified as Cfa (Köppen), with average temperature and precipitation of $19.4{ }^{\circ} \mathrm{C}$ and $1440 \mathrm{~mm}$, respectively. The calculated erosivity index for the study site was 5,604.5 $\mathrm{MJ} \mathrm{mm} \mathrm{ha}^{-1}$ year ${ }^{1}$ (CASSOL et al., 2018) for a 13-year series of data.

The soil of the experimental area was classified as Ultisol (IUSS WORKING GROUP WRB, 2015), which corresponds to an typical red yellow dystrophic Argissolo, according to the Brazilian Soil Classification System (CASSOL et al., 2018) with a sandy clay loam texture.

\section{History and experimental design}

The experiment was initiated in June 2004 (FONSECA, 2006). The experiment was conducted in experimental plots of $8 \mathrm{~m}^{2}(0.8 \mathrm{~m}$ wide $\times 10 \mathrm{~m}$ long), with four repetitions arranged in the direction of the slope of the land (average slope $8.1 \%$ ).

From 2004 to 2010, the experiment was conducted using the sequence black oats (Avena strigosa) + vetch (Vicia sativa) during winter and corn (Zea mays sp.) in summer. The winter crops were sown without soil preparation and the summer crops with different preparations and sources of fertilisation applied annually. The soil management types were conventional tillage (CT) and no-tillage (NT); the latter, is important to note of crop rotation was not met in the experiment. In both soil management systems, four fertilization treatments were applied: no fertilization (W; control), mineral fertilization (M), organic fertilization with urban waste compost (UWC), and organic fertilisation with pig slurry (PS). Organic manure compost was acquired from the sorting and composting of the Municipal Department of Urban Cleaning of Porto Alegre (DMLU) located in Lomba do Pinheiro, Porto Alegre/RS. The organic pig manure was obtained from the Zootechny Department of the Agronomy Faculty of the Federal University of Rio Grande do Sul.

The chemical characteristics during the sixth year of the experiment (2009/2010) are shown in table 1. All nutrients, except $\mathrm{P}$ in the control treatment, were above the critical content for the development of corn crops, as well as the $\mathrm{pH}$ values (SOLO, 2004).

In NT, the fertilizers were applied to the soil surface, whereas in $\mathrm{CT}$, they were incorporated with the aid of a scarifier at a depth of $20 \mathrm{~cm}$, followed by manual soil turning. The added doses were calculated according to the fertilization and liming recommendations for the states of Rio Grande do Sul and Santa Catarina (SOLO, 2004) for a yield of 8 ton ha ${ }^{-1}$ for corn crops.

To meet the nutritional demands for mineral fertilization, $267 \mathrm{~kg} \mathrm{ha}^{-1}$ of urea, $117 \mathrm{~kg} \mathrm{ha}^{-1}$ of triple superphosphate, and $117 \mathrm{~kg} \mathrm{ha}^{-1}$ of potassium chloride were applied. Thus, meeting the demand of $120 \mathrm{~kg} \mathrm{ha}^{-1}$ of N, $125 \mathrm{~kg} \mathrm{ha}^{-1}$ of $\mathrm{P}_{2} \mathrm{O}_{5}$, and $70 \mathrm{~kg} \mathrm{ha}^{-1}$ $\mathrm{K}_{2} \mathrm{O}$ in mineral form. The urban waste compost was applied at a total of $10000 \mathrm{~kg} \mathrm{ha}^{-1}$ to supply $120 \mathrm{~kg}$ $\mathrm{ha}^{-1}$ of N, $192 \mathrm{~kg} \mathrm{ha}^{-1}$ of $\mathrm{P}_{2} \mathrm{O}_{5}$, and $40 \mathrm{~kg} \mathrm{ha}^{-1} \mathrm{~K}_{2} \mathrm{O}$. Regarding pig manure, $11,160 \mathrm{~kg} \mathrm{ha}^{-1}$ was applied to supply $120 \mathrm{~kg} \mathrm{ha}^{-1}$ of N, $316 \mathrm{~kg} \mathrm{ha}^{-1}$ of $\mathrm{P}_{2} \mathrm{O}_{5}$, and 239 $\mathrm{kg} \mathrm{ha}^{-1} \mathrm{~K}_{2} \mathrm{O}$.

Maize was sown by hand to obtain two to three seeds per pit and $20 \mathrm{~cm}$ spacing between plants in the row with only one sowing row in each plot.

\section{High-intensity rainfall test}

In 2010 (the sixth year of the experiment), $45 \mathrm{~d}$ after the application of fertilization and sowing of corn, a simulated rainfall lasting 90 min with an intensity of $120 \mathrm{~mm} \mathrm{~h}^{-1}$ was administered with a 
Table 1 - Chemical characterization of the soil at the end of 5 years of experimentation at three depths in different soil management systems and with different types of organic and mineral fertilization.

\begin{tabular}{|c|c|c|c|c|c|c|c|c|}
\hline \multirow[t]{2}{*}{ Fertilisation } & \multicolumn{8}{|c|}{ 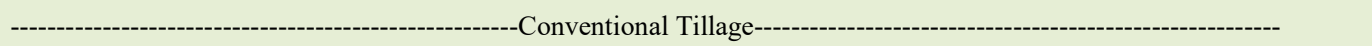 } \\
\hline & $\mathrm{OM}$ & CTC & $\mathrm{pH}$ & $\mathrm{P}$ & K & $\mathrm{Ca}$ & $\mathrm{Mg}$ & $\mathrm{BD}$ \\
\hline \multicolumn{9}{|c|}{ 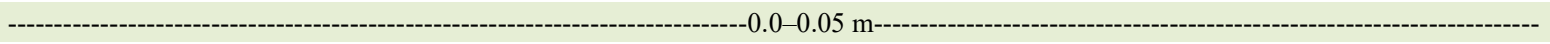 } \\
\hline W & 2.1 & 8.0 & 5.8 & 5.2 & 268.0 & 2.8 & 1.8 & 1.36 \\
\hline M & 1.9 & 8.1 & 5.5 & 30.3 & 304.0 & 2.0 & 1.3 & 1.24 \\
\hline UWC & 3.4 & 11.0 & 6.5 & 64.3 & 292.3 & 6.0 & 2.2 & 1.15 \\
\hline PS & 2.9 & 9.3 & 6.0 & 90.8 & 358.3 & 3.1 & 2.4 & 1.20 \\
\hline \multicolumn{9}{|c|}{ 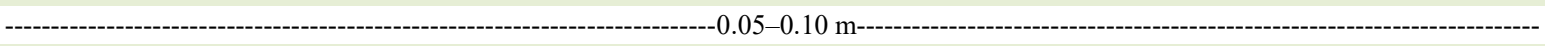 } \\
\hline W & 1.8 & 7.6 & 5.6 & 3.5 & 196.5 & 2.4 & 1.4 & 1.46 \\
\hline M & 2.0 & 8.0 & 5.1 & 15.0 & 151.3 & 2.2 & 1.2 & 1.50 \\
\hline UWC & 2.1 & 8.8 & 6.3 & 25.8 & 192.5 & 4.7 & 1.6 & 1.22 \\
\hline PS & 1.9 & 8.7 & 5.6 & 57.0 & 262.0 & 2.5 & 1.8 & 1.48 \\
\hline \multicolumn{9}{|c|}{ 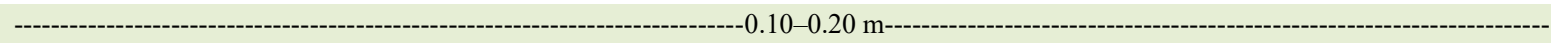 } \\
\hline W & 1.6 & 7.9 & 5.3 & 3.8 & 125.8 & 2.6 & 1.6 & 1.37 \\
\hline M & 1.6 & 8.6 & 5.1 & 7.5 & 103.8 & 2.7 & 1.5 & 1.53 \\
\hline UWS & 1.6 & 8.5 & 5.6 & 7.5 & 117.8 & 3.3 & 1.6 & 1.40 \\
\hline PS & 1.8 & 8.9 & 5.5 & 43.3 & 191.3 & 2.6 & 2.0 & 1.55 \\
\hline \multicolumn{9}{|l|}{ Fertilisation } \\
\hline & $\mathrm{OM}$ & CTC & $\mathrm{pH}$ & $\mathrm{P}$ & $\mathrm{K}$ & $\mathrm{Ca}$ & $\mathrm{Mg}$ & $\mathrm{BD}$ \\
\hline \multicolumn{9}{|c|}{ 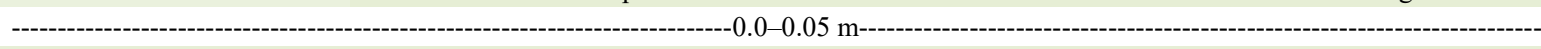 } \\
\hline W & 2.4 & 7.9 & 5.8 & 6.9 & 230.8 & 2.9 & 1.7 & 1.35 \\
\hline M & 2.6 & 8.7 & 5.5 & 24.8 & 277.5 & 2.6 & 1.5 & 1.38 \\
\hline UWC & 3.4 & 12.2 & 6.6 & 93.3 & 254.3 & 7.4 & 2.4 & 1.03 \\
\hline PS & 2.5 & 9.8 & 5.8 & 92.0 & 243.0 & 3.7 & 2.5 & 1.29 \\
\hline \multicolumn{9}{|c|}{ - } \\
\hline W & 1.6 & 7.0 & 5.5 & 3.1 & 174.0 & 2.3 & 1.4 & 1.71 \\
\hline M & 1.7 & 7.2 & 5.3 & 10.5 & 188.5 & 2.0 & 1.2 & 1.75 \\
\hline UWC & 2.0 & 8.4 & 6.0 & 17.2 & 178.0 & 3.8 & 1.7 & 1.52 \\
\hline PS & 1.8 & 8.3 & 5.5 & 71.0 & 190.8 & 2.3 & 2.2 & 1.58 \\
\hline \multicolumn{9}{|c|}{ 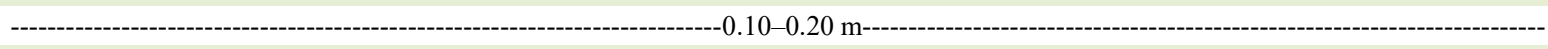 } \\
\hline W & 1.3 & 8.5 & 5.3 & 3.3 & 150.8 & 2.8 & 1.7 & 1.68 \\
\hline M & 1.4 & 7.7 & 5.3 & 4.7 & 139.8 & 2.2 & 1.3 & 1.62 \\
\hline UWC & 1.6 & 8.5 & 5.6 & 6.9 & 147.5 & 3.2 & 1.6 & 1.62 \\
\hline $\mathrm{PC}$ & 1.5 & 8.5 & 5.3 & 47.0 & 161.5 & 2.2 & 2.1 & 1.64 \\
\hline
\end{tabular}

$\mathrm{OM}=$ organic matter $(\%) ; \mathrm{CTC}$ a $\mathrm{pH} 7.0=$ cation exchange capacity $\left(\mathrm{cmol}_{\mathrm{c}} \mathrm{dm}^{-3}\right) ; \mathrm{pH}$ in $\mathrm{H}_{2} \mathrm{O} ; \mathrm{P}=$ phosphorus $\left(\mathrm{mg} \mathrm{dm}^{-3}\right) ; \mathrm{K}=$ potassium $\left(\mathrm{mg} \mathrm{dm}^{-3}\right) ; \mathrm{Ca}=$ calcium $\left(\mathrm{cmol}_{\mathrm{c}} \mathrm{dm}^{-3}\right) ; \mathrm{Mg}=$ magnesium $\left(\mathrm{cmol}_{\mathrm{c}} \mathrm{dm}^{-3}\right) ; \mathrm{BD}=$ bulk density $\left(\mathrm{Mg} \mathrm{m}^{-3}\right) ; \mathrm{W}=$ no fertilisation $(\mathrm{control}) ; \mathrm{M}=$ mineral fertilization; $\mathrm{UWC}=$ organic fertilisation with urban waste compost, $\mathrm{PS}=$ organic fertilisation with pig slurry.

rotating arm simulator, as described and calibrated by CASSOL, E. A.; GUERRA (1978). A visualization of the experiment at the time of the simulated rainfall test can be seen in figure 1 .

As a complementary analysis before the start of the simulated rainfall application, soil samples were collected at depths of $0-0.10 \mathrm{~m}$ and $0.10-0.20$ $\mathrm{m}$ with the aid of a Dutch auger to evaluate soil moisture and bulk density with three repetitions for each plot. The samples for soil moisture were packed in aluminium cans, sealed, identified, and taken to the laboratory where they were weighed before and after drying in an oven for $24 \mathrm{~h}$ at $100-105^{\circ} \mathrm{C}$ (DONAGEMA et al., 2011). Samples for bulk density were collected in cylindrical rings $4 \mathrm{~cm}$ high, with a $5.67 \mathrm{~cm}$ internal diameter. They were taken to the laboratory and were kept in an oven at $100-105^{\circ} \mathrm{C}$ for $48 \mathrm{~h}$, weighed, and their dry weight was used to calculate the mass/volume ratio and thereby the density of the soil $\left(\mathrm{Mg} \mathrm{m}^{-3}\right)$ (DONAGEMA et al., 2011).

Ciência Rural, v.50, n.10, 2020. 


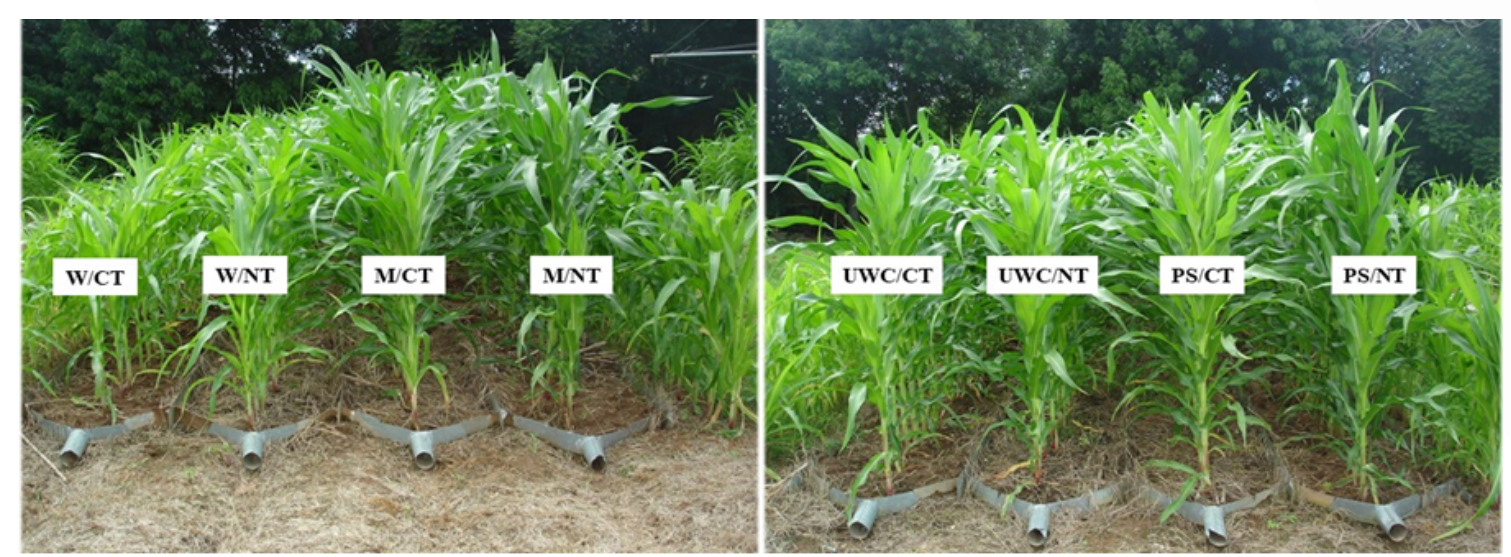

Figure 1 - Visualization of the experiment at the time of the simulated rainfall test. $\mathrm{CT}=$ conventional tillage; NT=no-tillage; W= no fertilisation (control); $\mathrm{M}=$ mineral fertilization; $\mathrm{UWC}=$ organic fertilisation with urban waste compost; PS = organic fertilization with pig slurry.

Sampling of water, sediment, and nutrients during a high-intensity event

At the beginning of the runoff, water+sediment samples, allocated in plastic pots with $1 \mathrm{~L}$ capacity, were collected every 3 min until the end of the simulated rainfall and runoff for a set time, varying according to the runoff volume generated. These samples were used to determine (i) runoff rates, (ii) water infiltration, and (iii) suspended sediment concentration for soil loss estimation. The runoff rate was calculated considering the sampled volume during the time of collection every $3 \mathrm{~min}$. The infiltration rate was obtained from the difference between rainfall intensity and runoff rate.

Similarly, the collection was used to evaluate the concentration of nutrients in soluble form with the generation of runoff occurring every $3 \mathrm{~min}$ for an accumulated period of 15 min to obtain a composite sample at the end totalling six composite samples (six samples $\times 15 \mathrm{~min}=90 \mathrm{~min}$ of simulated rainfall). Thus, in the six composite samples, $200 \mathrm{~mL}$ aliquots were removed from each sample and stored in glass flasks for the determination of the concentrations of phosphorus, potassium, calcium, and magnesium in the runoff in addition to $\mathrm{pH}$ and electrical conductivity (EC). All samples were packed in Styrofoam with ice and sent to the Laboratory of Soil Chemistry and Fertility of the Federal University of Rio Grande do Sul.

\section{Laboratory analysis}

The suspended sediment concentration was determined using the samples collected every
$3 \mathrm{~min}$ in $1 \mathrm{~L}$ capacity containers. The analyses were performed in the Erosion Laboratory of the Federal University of Rio Grande do Sul, where they were weighed and allocated to an oven at $50{ }^{\circ} \mathrm{C}$ until the evaporation of all water. Next, samples were weighed (recipient + sediment) and then only the "clean" container was weighed to obtain the solid mass (g) that was in the water+sediment sample.

The $\mathrm{pH}$ readings were performed with a potentiometer with a glass electrode, and the EC was determined with a conductivity meter $\left(\right.$ at $\left.\mu \mathrm{Scm}^{-1}\right)$. For the other analyses, the composite samples were filtered through a $0.45 \mu \mathrm{m}$ Millipore filter to obtain the soluble fraction. Thus, the concentrations of $\mathrm{P}$ determined colorimetrically by Murphy and Riley (1962) method, K was determined by atomic emission spectrometry (flame photometer), and $\mathrm{Ca}$ and $\mathrm{Mg}$ were determined by atomic absorption spectrometry, according to TEDESCO et al., (1995).

\section{Analysis of data}

Water infiltration rates $\left(\mathrm{mm} \mathrm{h}^{-1}\right)$ for the soil were determined by the difference between the rate of rainfall $\left(\mathrm{mm} \mathrm{h}^{-1}\right)$ applied and the rate of runoff $(\mathrm{mm}$ $\mathrm{h}^{-1}$ ). Evaporation rates and rainfall interception by vegetation were considered negligible. From the total water loss $(\mathrm{mm})$ and the precipitated volume $(\mathrm{mm})$, the runoff coefficient (\%) was calculated. This was obtained by the ratio of the runoff to precipitation and multiplying by 100 to obtain the percentage.

Total losses of water $(\mathrm{mm})$ and soil $(\mathrm{kg}$ $\mathrm{ha}^{-1}$ ) were obtained by integrating the samples every 3 
min during runoff generation and sediment transport. The total nutrient losses $\left(\mathrm{kg} \mathrm{ha}^{-1}\right)$ were calculated by multiplying the average concentration of each nutrient obtained $\left(\mathrm{mg} \mathrm{L}^{-1}\right)$ by the total volume of runoff generated $(\mathrm{L}$ ) in each soil management system and fertilization source. It is important to note that the soil and water loss data were adjusted for the average slope of the plots, $0.081 \mathrm{~m} \mathrm{~m}^{-1}$, and rainfall intensity of $120 \mathrm{~mm} \mathrm{~h}^{-1}$ according to CASSOL et al. (1999).

Results were subjected to a two-factor analysis of variance, with factors being the type of soil management (NT and CT) and type of soil fertilisation (W, M, UWC, and PS). When the interaction between the types of management and soil fertilisation was not observed, the effects of each treatment were compared separately. The means were compared using the Tukey test at $\mathrm{p}<0.05$ using the SISVAR statistical program.

\section{RESULTS AND DISCUSSION}

Hydrologic analysis of the high-intensity rainfall event Climate phenomena, such as El Niño, are responsible for the increase in the volume and intensity of rainfall in southern Brazil (OBREGÓN; MARENGO, 2007), and have been observed more frequently (ANA; IBGE, 2020). Between the period of sowing of corn until the occurrence of the simulated rainfall test, natural rainfalls totalled $351 \mathrm{~mm}$. Only during December 2009, a rainfall volume of $259 \mathrm{~mm}$ occurred while the monthly average for December in Porto Alegre was $101 \mathrm{~mm}$ (Centro Integrado de Comando - CEIC).

Previous rainfall has a significant effect on the generation of runoff (SARKAR et al., 2015). In this study, the treatments showed no significant difference in relation to soil moisture as a function of antecedent rainfall. Thus, the soil moisture (gravimetric) was homogeneous and ranged from 0.17 to $0.21 \mathrm{~kg}^{-1}$ in the 0.0 to $0.10 \mathrm{~m}$ layer, and 0.15 to $0.17 \mathrm{~kg}^{-1}$ in the 0.0 to $0.20 \mathrm{~m}$ layer.

The infiltration rate of water into the soil was lower in the NT compared to that in the CT; consequently, the highest runoff rates occurred in the NT (Figure 2). Both preparations had, on average, the same runoff start time, which occurred 22 min after the onset of rainfall. Bulk density values close to $1.8 \mathrm{Mg} \mathrm{m}^{-3}$ are considered harmful to air and water flows in sandy soils, such as that at the study site (HOLTHUSEN et al., 2018; REICHERT et al., 2009). Values of this magnitude were reported for NT compared to that for CT (Table 1) in the 0.05 to $0.10 \mathrm{~m}$ layer.

The treatment source of fertilization was analysed according to the type of soil management, and the values in the graph represent an average of four repetitions (Figures 3A, 3B, 3C, and 3D).

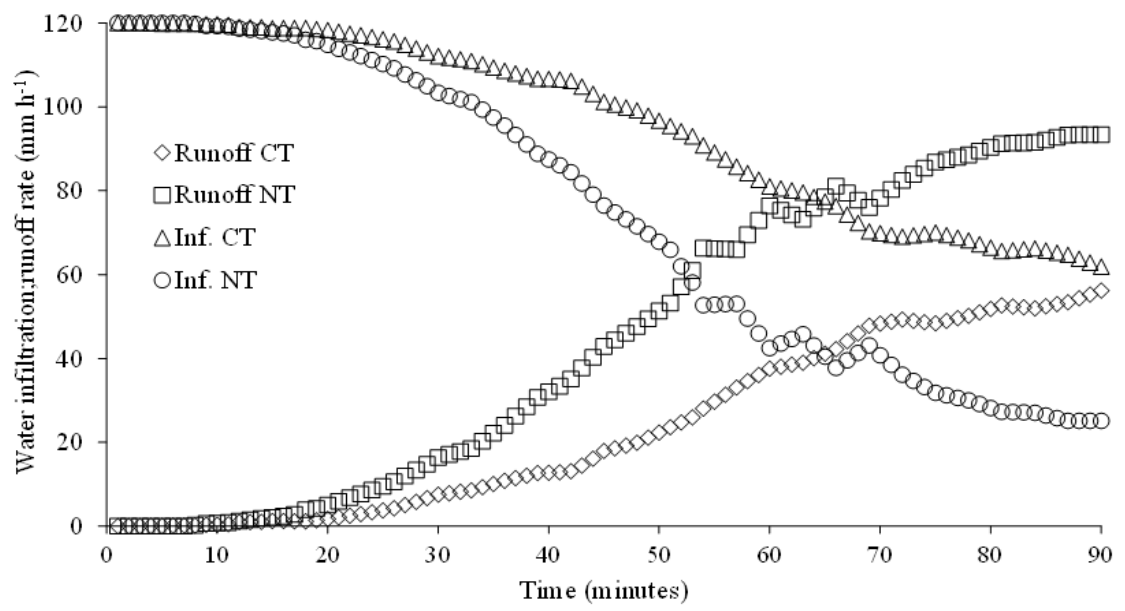

Figure 2 - Rates of water infiltration and runoff. Runoff CT and Runoff NT= runoff in conventional tillage and no-tillage, respectively; Inf. CT and Inf. NT = water infiltration in conventional tillage and no-tillage, respectively. Each value is an average of 16 repetitions. 
All fertilization sources and the control presented higher runoff rates in the NT compared to that in the CT (Figures 3A, 3B, 3C, and 3D). The control and mineral fertilisation sources began to runoff at 12 and $18 \mathrm{~min}$, respectively. On the other hand, fertilisation with PS started the runoff at $27 \mathrm{~min}$, and the UWC at $29 \mathrm{~min}$.

The highest water infiltration rates in the soil occurred for the urban waste compost (both in CT and NT), followed by treatment with pig manure (Figure 3C and 3D, respectively,). These results are in accordance with a simulated rainfall test with an intensity of $80 \mathrm{~mm} \mathrm{~h}^{-1}$, which measured the runoff and infiltration rates in plots with bovine manure application (1 year before the simulated rainfall application) and on plots without fertilization. The authors concluded that the application of manure increased the infiltration rates of water in the soil up to $26 \%$ and increased the time when surface runoff began (RAMOS; MARTÍNEZCASASNOVAS, 2006a).

Comparing the sources of fertilization within each soil preparation in the $0.0-0.05 \mathrm{~m}$ layer, the bulk density was higher for CT in the UWC treatment $\left(1.15 \mathrm{Mg} \mathrm{m}^{-3}\right)$ in relation to that of NT (1.03 $\left.\mathrm{Mg} \mathrm{m}^{-3}\right)$. The values were lower when we analysed the UWC treatment in relation to other fertilization treatments and lower than results in the literature (HOLTHUSEN et al., 2018).

Therefore, it was observed that the highest rates of runoff occurred in the system considered conservationist i.e, the NT system. Characteristics such as surface roughness, bulk, and soil porosity at a given rainfall intensity (TIWARI et al., 2009) may have a greater influence on the infiltration and runoff processes, independent of the soil management

\section{A.}

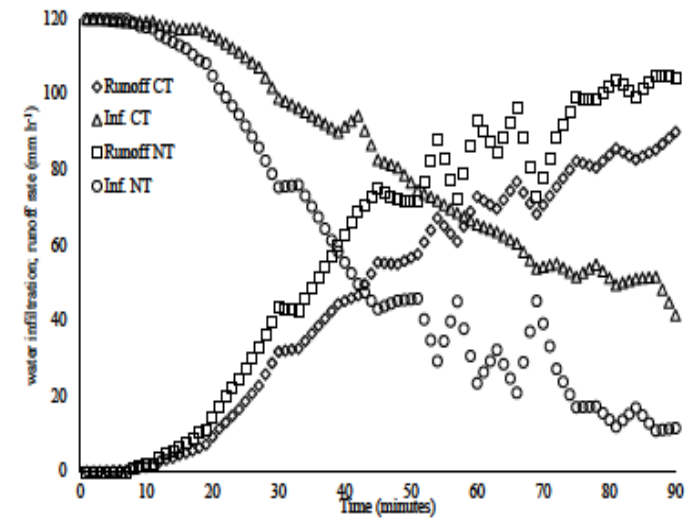

C.

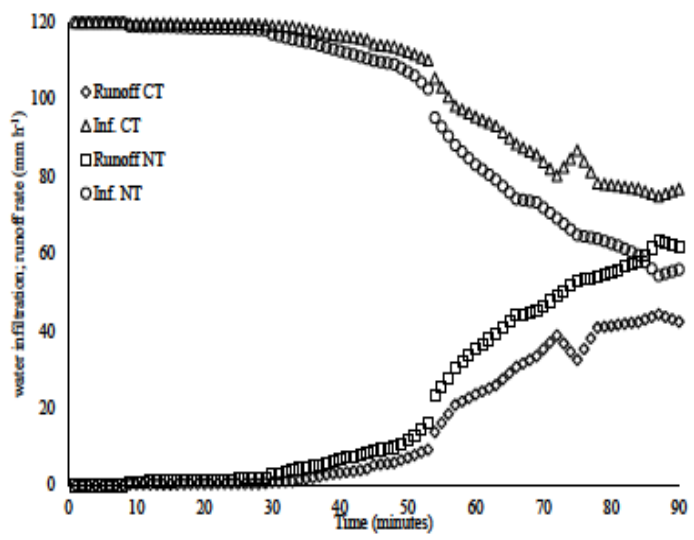

B.

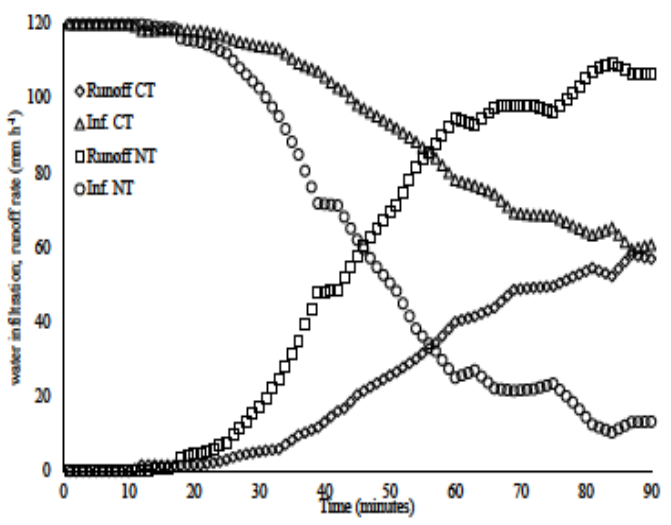

D.

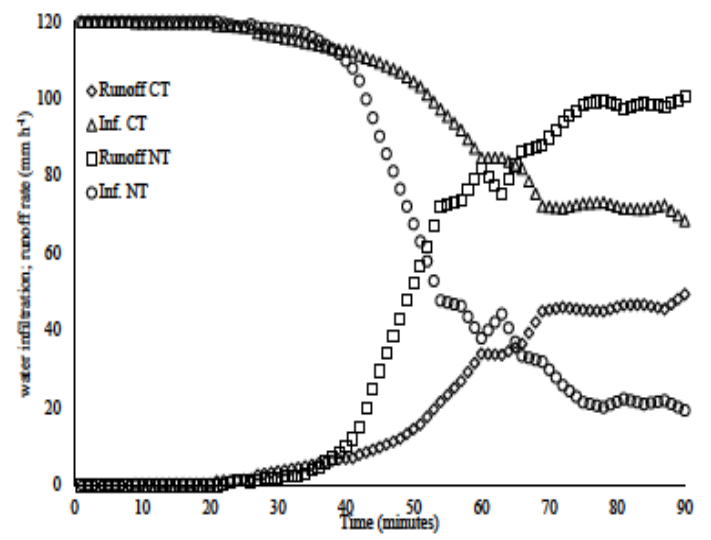

Figure 3 - Rates of water infiltration and runoff: (A) control, (B) mineral fertilization, (C) organic fertilization with urban waste compost, and (D) organic fertilisation with pig slurry. Runoff CT and Runoff NT = runoff in conventional tillage and no-tillage, respectively; Inf. TC and Inf. NT = water infiltration in conventional tillage and no-tillage, respectively. Each value represents an average of four repetitions.

Ciência Rural, v.50, n.10, 2020. 
system used. This result is different from that of BERTOL et al. (2003) who used a lower intensity of $64 \mathrm{~mm} \mathrm{~h}^{-1}$. The highest rates of runoff generated the highest water losses in the tillage system and bare soil (BERTOL et al., 2003).

The surface runoff coefficient (C), which portrays the fraction of rainfall that flowed superficially, was influenced by both soil management and fertilization systems. Comparing the soil management effect, the average value of $\mathrm{C}$ for the NT was 0.77 , which indicated that $77 \%$ of the simulated rainfall became runoff. Conversely, the $\mathrm{CT}$ reached an average value of $\mathrm{C}$ equal to 0.45 , which was significantly different $(\mathrm{P}<0.05)$. Regarding the fertilization treatment, $\mathrm{C}$ ranged from 0.44 with UWC fertilization to 0.72 for the control. $\mathrm{M}$ fertilization had a $\mathrm{C}$ close to that of the control at 0.69 . This result differed from that reported by BERTOL et al. (2007), where the highest runoff rates occurred for organic fertilisation and not mineral fertilization. The authors attributed this fact to the time between fertilization application and simulated rainfall tests of $16 \mathrm{~h}$, which allowed the entry of solid organic compounds into the macropores and the effect of hydrophobicity in soil (VOGELMANN et al., 2013). In this study, the highest concentration of natural rainfall and the application of simulated rainfall occurred more than $16 \mathrm{~h}$ after the application of organic and mineral fertilizers, in agreement with other results in the literature (RAMOS; MARTÍNEZ-CASASNOVAS, 2006a).

\section{Chemical characterisation and concentration of nutrients in the runoff}

The soil chemical analysis (Table 1) performed in the year of the experiment (2009-2010) showed the highest concentration of all nutrients and soil organic matter content for the layer of $0.0-0.05 \mathrm{~m}$ compared to that of the others. The highest $\mathrm{P}$ content occurred for organic sources in the NT, especially the UWC (Table 1). Despite the beneficial effects of the use of organic fertilizers, in areas under NT, there may be an accumulation of nutrients in the topsoil, favouring the transfer of nutrients through runoff (BERTOL et al., 2010).

The $\mathrm{pH}$ and EC values may serve as indicators of runoff quality (BERTOL et al., 2007). In this study, $\mathrm{pH}$ and $\mathrm{EC}$ did not differ between soil management systems, nor did they differ among fertilization sources and in the interactions. The $\mathrm{pH}$ showed high values in the runoff, with the mean for the types of soil management being 6.56 for CT and 6.66 for NT, close to the values for the different fertilisation sources. Similarly, the mean values for EC were 43.78 and $44.51 \mu \mathrm{S} \mathrm{cm}^{-1}$ for CT and NT, respectively, and similar values occurred for types of fertilization.

The concentrations of $\mathrm{P}, \mathrm{K}, \mathrm{Ca}$, and $\mathrm{Mg}$ did not exhibit an interaction between the fertilisation treatments and soil management treatments. However, by soil management, $\mathrm{K}$ was significantly different $(\mathrm{P}<0.05)$. Analysing the effects of fertilization treatment, the concentrations of $\mathrm{P}$ and $\mathrm{K}$ in treatment PS varied significantly from that of other fertilization sources (Table 2). The $\mathrm{Ca}$ varied significantly for UWC from that of other sources, whereas $\mathrm{Mg}$ did not vary significantly among the fertilization sources (Table 2).

The concentration of soluble $\mathrm{P}$ was high in all treatments, even though it was preferentially adsorbed by the sediment (RAMOS; MARTÍNEZCASASNOVAS, 2006b; TANG et al., 2019). Its concentrations varied from 1.21 (CT) to 1.73 (NT) mg $\mathrm{L}^{-1}$ when comparing the soil management effects and from 1.06 to $2.48 \mathrm{mg} \mathrm{L}^{-1}$ for the fertilization source effects (Table 2). On this monitoring scale of small experimental plots, we did not have the formation of concentrated flow and did not consider the effect of the landscape (shape of the slope and connectivity with the drainage network). Therefore, the diffuse flow may not reach the rivers and cause problems with river contamination. However, it should be noted that if we consider this concentration of $\mathrm{P}$ soluble in watercourses, according to Resolution of CONAMA (2005) for Class I freshwaters, the values are at least four times higher than that allowed by legislation, as found by BENDER et al. (2018). The soluble form of the nutrients, $\mathrm{P}, \mathrm{K}, \mathrm{Ca}$, and $\mathrm{Mg}$ is the form in which they will be available in the aqueous environment and may trigger new reactions or processes (TANG et al., 2019). Thus, when transported by surface runoff, they can cause environmental effects depending on the concentrations that reach watercourses (ZHANG et al., 2014).

\section{Total losses of water, soil, and nutrients in soluble form}

Regarding the soil management systems, CT presented higher soil losses relative to NT (Table 3 ), with significant differences $(p<0.05)$ only for the control. When the effect of the fertiliser sources on NT was compared, there were no significant differences between the fertilization sources, whereas for $\mathrm{CT}$, the organic sources varied significantly from the others (Table 3 ). These results corroborated those in the literature, indicating that conventional tillage systems lose more soil than conservationists systems 
Table 2 - Concentrations of nutrients available in runoff in different treatments with organic and mineral fertilisation.

\begin{tabular}{|c|c|c|c|c|}
\hline \multirow[t]{2}{*}{ Fertilisation } & \multicolumn{4}{|c|}{ 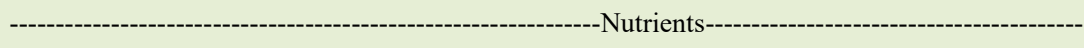 } \\
\hline & $P$ & $\mathrm{~K}$ & $\mathrm{Ca}$ & $\mathrm{Mg}$ \\
\hline \multicolumn{5}{|c|}{ 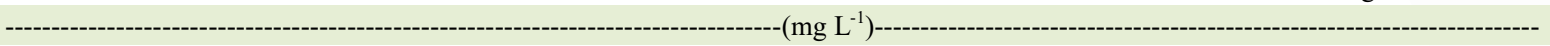 } \\
\hline W & $1.06 \mathrm{~b}$ & $14.79 \mathrm{a}$ & $1.58 \mathrm{~b}$ & $1.84 \mathrm{a}$ \\
\hline M & $1.16 \mathrm{~b}$ & $12.79 \mathrm{a}$ & $1.74 \mathrm{~b}$ & $1.92 \mathrm{a}$ \\
\hline UWC & $1.19 \mathrm{~b}$ & $12.51 \mathrm{a}$ & $3.53 \mathrm{a}$ & $2.50 \mathrm{a}$ \\
\hline PS & $2.48 \mathrm{a}$ & $9.38 \mathrm{~b}$ & $1.74 \mathrm{~b}$ & $2.08 \mathrm{a}$ \\
\hline CV (\%) & 76.56 & 61.27 & 48.74 & 31.03 \\
\hline
\end{tabular}

Averages followed by the same letter in a column do not differ by Tukey's test at $5 \%$. $\mathrm{CV}=$ coefficient of variation; $\mathrm{W}=$ no fertilisation (control); $\mathrm{M}=$ mineral fertilization; UWC = organic fertilisation with urban waste compost; PS = organic fertilization with pig slurry. Each value represents an average of eight repetitions.

(ANACHE et al., 2017). Conversely, we observed the greatest water losses for NT, regardless of whether we compared soil management, fertilization, or their interactions (Table 3).

The water loss ( $\mathrm{mm})$, considering the effect of soil management, was 1.87 times higher in NT than in CT. Regarding the effect of the fertilization source, water losses were higher in the control, followed by the mineral fertilizers. Urban waste compost had the lowest water loss, representing $0.4 \%$ of the total water loss in the control treatment (Table 3).

For the interaction between soil management and fertilization, there were no significant interactions for the total loss of nutrients. Therefore, a separate analysis of the effect of each treatment was performed. Regarding the effect of soil management, all four elements $(\mathrm{P}, \mathrm{K}, \mathrm{Ca}$, and
$\mathrm{Mg})$ differed significantly $(\mathrm{P}<0.05)$, with the NT being the treatment with the highest losses $(\mathrm{kg})$ per hectare for all nutrients.

When analysing the effect of the fertilisation treatment, the differences were significant between phosphorus and potassium, whereas between calcium and magnesium there was no statistical difference (Table 4). This may have occurred because of the low concentration of these nutrients in the soil (Table 1).

As shown in table 4, the losses of $\mathrm{P}$ were significantly different between the two organic fertilisers. P losses in treatment PS were 3.4 times higher than those with UWC fertilization. Total soluble P losses for the PS treatment were $1.26 \mathrm{~kg} \mathrm{~h}^{-1}$, a value that could be considered high and worrisome during extreme high-intensity events $(120 \mathrm{~mm}$

Table 3 - Total water and soil losses in different soil management and fertilisation treatments.

\begin{tabular}{|c|c|c|c|c|c|c|}
\hline \multirow[t]{2}{*}{ Fertilisation } & \multicolumn{3}{|c|}{-------------------Water losses (mm)--------------------- } & \multicolumn{3}{|c|}{ 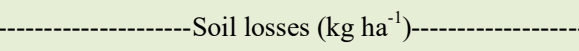 } \\
\hline & $\mathrm{CT}$ & NT & Average & CT & NT & Average \\
\hline W & 58.7 a B & 96.6 a A & 77.7 & 1035 a A & 370 a B & 703 \\
\hline M & $42.3 \mathrm{ab} \mathrm{B}$ & 93.7 a A & 68.0 & $837 \mathrm{ab} A$ & 440 a A & 639 \\
\hline UWC & $25.5 \mathrm{~b} \mathrm{~A}$ & $36.5 \mathrm{~b} \mathrm{~A}$ & 31.0 & $415 \mathrm{~b} \mathrm{~A}$ & 266 a A & 341 \\
\hline $\mathrm{PC}$ & $32.0 \mathrm{ab} \mathrm{B}$ & 69.6 a A & 50.8 & $467 \mathrm{~b} \mathrm{~A}$ & 405 a A & 436 \\
\hline Average & 39.7 & 74.1 & 56.9 & 689 & 370 & 530 \\
\hline $\mathrm{CV}(\%)$ & 42.4 & 43.9 & 54.3 & 58 & 57 & 67 \\
\hline
\end{tabular}

Averages followed by the same letter in a column do not differ by Tukey's test at $5 \%$. CV= coefficient of variation;CT=conventional tillage; NT=no-tillage; $\mathrm{M}=$ mineral fertilization; $\mathrm{UWC}=$ organic fertilisation with urban waste compost; $\mathrm{PS}=$ organic fertilization with pig slurry.

Each value represents an average of four repetitions. 
Table 4 - Total loss of nutrients available in runoff in different treatments with organic and mineral fertilization.

\begin{tabular}{|c|c|c|c|c|}
\hline \multirow[t]{2}{*}{ Fertilisation } & \multicolumn{4}{|c|}{---Nutrients $\left(\mathrm{kg} \mathrm{ha}^{-1}\right)$} \\
\hline & $P$ & $\mathrm{~K}$ & $\mathrm{Ca}$ & $\mathrm{Mg}$ \\
\hline W & $0.82 \mathrm{ab}$ & $11.49 \mathrm{a}$ & $1.23 \mathrm{a}$ & $1.43 \mathrm{a}$ \\
\hline M & $0.80 \mathrm{ab}$ & $8.10 \mathrm{~b}$ & $1.18 \mathrm{a}$ & $1.30 \mathrm{a}$ \\
\hline UWC & $0.37 \mathrm{~b}$ & $3.88 \mathrm{~b}$ & $1.09 \mathrm{a}$ & $0.78 \mathrm{a}$ \\
\hline PS & $1.26 \mathrm{a}$ & $4.77 b$ & $0.88 \mathrm{a}$ & $1.05 \mathrm{a}$ \\
\hline CV (\%) & 76.56 & 61.27 & 48.74 & 31.03 \\
\hline
\end{tabular}

Averages followed by the same letter in a column do not differ by Tukey's test at $5 \%$. CV= coefficient of variation; $\mathrm{M}=$ mineral fertilisation; UWC $=$ organic fertilisation with urban waste compost; PS = organic fertilisation with pig slurry. Each value represents an average of eight repetitions.

$\mathrm{h}^{-1}$ ). In the northeast region of Spain, researchers evaluated total $\mathrm{P}$ and $\mathrm{N}$ losses in a vineyard area during 17 natural rainfall events (precipitation varied from 17.4 to $217.2 \mathrm{~mm}$ ) and obtained export rates of $8 \mathrm{~kg} \mathrm{ha}^{-1}$ year ${ }^{-1}$ for nitrogen and $6.5 \mathrm{~kg} \mathrm{ha}^{-1}$ year $^{-1}$ for phosphorus (RAMOS; MARTÍNEZCASASNOVAS, 2006b).

$\mathrm{K}$ was the nutrient with the highest losses $(\mathrm{kg})$ per hectare (Table 4). Regarding significant differences $(\mathrm{P}<0.05)$, only the control differed with that of other treatments (Table 4). BARROS et al. (2020) evaluated the losses of soluble N-P-K in seven events of natural rainfall in 2018 in a small rural watershed $\left(1.23 \mathrm{~km}^{2}\right)$ and observed 9.9, 4.8, and $0.06 \mathrm{~kg} \mathrm{ha}^{-1}$ of $\mathrm{K}, \mathrm{N}$ and $\mathrm{P}$, delivered to the stream, respectively.

In the 2008/2009 crops year, the dry matter input was measured and the average of the two soil management systems, the UWC treatment contributed $15 \mathrm{Mg} \mathrm{ha}^{-1}$, PS and M contributed $13 \mathrm{Mg}$ $\mathrm{ha}^{-1}$, and the control $9 \mathrm{Mg} \mathrm{ha}^{-1}$. In the winter of 2009 , the dry mass of oats +vetch was higher for the same treatment (UWC); although, the difference between the other treatments was small (UWC treatment was 1.56; PS treatment 1.52; M treatment 1.36, and the control 1.26 Mg ha-1).

The higher contribution of dry matter added to the effect of bulk density (Table 1) may have promoted the best soil conditions for chemical, physical, and biological processes (CONCEIÇÃO; DIECKOW; BAYER, 2013; WINGEYER et al., 2015). Moreover, it was the treatment with the lowest losses of $\mathrm{K}\left(\mathrm{kg} \mathrm{ha}^{-1}\right)$, and among the lowest losses of $\mathrm{P}$.

Thus, the excess nutrients in the topsoil and the intensity of rains can transfer high amounts of water and nutrients from the soil to the watercourses, even in conservationists systems. Conversely, low concentrations of the chemical elements (metals, nutrients) in runoff does not mean lower losses $(\mathrm{kg})$ of these elements, because it is the volume and maximum rate of runoff that will lead to the magnitude of losses $\left(\mathrm{kg} \mathrm{ha}^{-1}\right)$ of these elements from the cropland.

\section{CONCLUSION}

The surface runoff rates in no-tillage systems were higher than those in the conventional tillage system under the conditions of the experiment, and fertilization with urban waste compost and with pig slurry provided increased rates of water infiltration. Organic fertilisers, especially pig slurry, were the treatments that generated the highest concentration of soluble $\mathrm{P}$ in surface runoff.

The conservationist soil system based on the minimum soil disturbance and cover plants was not sufficient to attenuate the effects of intense rainfall on the loss of water and nutrients in their soluble form, making them a source of pollution of rivers.

\section{ACKNOWLEDGEMENTS}

The authors would like to thank to Conselho Nacional de Desenvolvimento Científico e Tecnológico (CNPq), because of master scholarship. Furthermore, the authors are grateful to the "PROADE3" project by Fundação de Amparo à Pesquisa do Estado do Rio Grande do Sul (FAPERGS) n ${ }^{\circ} N^{\circ}$ 05/2211.9 for their support.

\section{DECLARATION OF CONFLICT OF INTERESTS}

The authors declare that there are no conflicts of interest. The financial support had no influence or role in the experimen-

Ciência Rural, v.50, n.10, 2020. 
tal design, data analysis, writing of the paper, or the decision to publish this paper.

\section{AUTHORS' CONTRIBUTION}

Authors 1 and 2 participated in the planning and execution of the experiment. Author 3 participated in the data analysis and writing of the manuscript, along with the participation of authors 1 and 2 .

\section{REFERENCES}

ANA; IBGE. Atlas Irrigação. Brasília: [s.n.]. Available from: $<$ https:// www.ana.gov.br/noticias/ana-e-ibge-lancam-levantamentosobre-uso-da-agua-na-agricultura-de-sequeiro-nobrasil-1/uso-da-agua-na-agricultura-de-sequeiro.pdf $>$. Accessed: Jul. 18, 2019.

ANACHE, J. A. A. et al. Runoff and soil erosion plot-scale studies under natural rainfall: A meta-analysis of the Brazilian experience. CATENA, v.152, p.29-39, 2017. Available from: $<$ http://dx.doi.org/10.1016/j.catena.2017.01.0030341-8162/>. Accessed: Jul. 18, 2019.

BARROS, C. A. P. et al. Dissolved N-P-K losses and their relation to the magnitude of rainfall event in a rural catchment. EGU General Assembly 2020. Anais... Vienna: 2020. Available from: <https://doi. org/10.5194/egusphere-egu2020-11892>. Accessed: Jul. 18, 2019.

BENDER, M. A. et al. Phosphorus dynamics during storm events in a subtropical rural catchment in southern Brazil. Agriculture, Ecosystems and Environment, v.261, n.July, p.93-102, 2018. Available from: <10.1016/j.agee.2018.04.004>. Accessed: Jul. 18, 2019.

BERTOL, I. et al. Nutrient losses by water erosion. p.581586, 2003. Available from: <https://doi.org/10.1590/S010390162003000300025>. Accessed: Jul. 18, 2019.

BERTOL, I. et al. Aspectos financeiros relacionados as perdas de nutrientes por erosão hídrica em diferentes sistemas de (1). R. Bras. Ci. Solo, v.31, n.1, p.133-142, 2007. Available from: <https: //doi. org/10.1590/S0100-06832007000100014> . Accessed: Jul. 18, 2019.

BERTOL, I. et al. Sedimentos transportados pela enxurrada em eventos de erosão hídrica em um nitossolo háplico. Revista Brasileira de Ciencia do Solo, v.34, n.1, p.245-252, 2010. Available from: $\quad<$ https://doi.org/10.1590/S0103-90162010000500013>. Accessed: Jul. 18, 2019.

CASSOL, E. A.; GUERRA, M. Calibração do primeiro simulador de chuvas de braços rotativos do Estado do Rio Grande do Sul. Passo Fundo: [s.n.].

CASSOL, E. A. et al. Infiltração de água e perdas de água e solo por erosão influenciadas por diferentes métodos de melhoramento da pastagem nativa gaúcha. Revista Brasileira de Ciência do Solo, 1999. Available from: <https://doi.org/10.1590/S010006831999000400019>. Accessed: Jul. 18, 2019.

CASSOL, E. A. et al. Soil Erodibility under Natural Rainfall Conditions as the $\mathrm{K}$ Factor of the Universal Soil Loss Equation and Application of the Nomograph for a Subtropical Ultisol. p.1-12, 2018. Available from: $<$ https://doi. org/10.1590/18069657rbcs20170262>. Accessed: Jul. 18, 2019.
Centro Integrado de Comando, Volume de Chuva, Média histórica de precipitação pluviométrica de Porto Alegre por mês, Available from: <https:/www2.portoalegre.rs.gov.br/ceic/ default.php?p_secao=28>. Accessed: Feb. 28, 2020.

CONAMA. Resolução n 357, 18 de março de 2005. Diário Oficial, n.053, p.58-63, 2005

CONCEIÇÃO, P. C.; DIECKOW, J.; BAYER, C. Combined role of no-tillage and cropping systems in soil carbon stocks and stabilization. Soil and Tillage Research, v.129, p.40-47, 2013. Available from: <https://doi.org/10.1016/j.still.2013.01.006>. Accessed: Feb. 28, 2020.

DECHEN, S. C. F. et al. Perdas e custos associados à erosão hídrica em função de taxas de cobertura do solo. Bragantia, v.74, n.2, p.224-233, 2015. Available from: <https://doi.org/10.1590/16784499.0363>. Accessed: Feb. 28, 2020

DEUSCHLE, D. et al. Erosion and hydrological response in no-tillage subjected to crop rotation intensification in southern Brazil. Geoderma, v.340, n.December 2018, p.157163, abr. 2019. Available from: <https://doi.org/10.1016/j. geoderma.2019.01.010>. Accessed: Feb. 28, 2020.

DONAGEMA, G. K. et al. Documentos 132 Manual de Métodos de. Embrapa, n.ISSN 1517-2627, p.230, 2011.

FONSECA, E. O. DA. Dinâmica do transporte de nutrientes no escoamento superficial em sistemas de manejo do solo. [s.l.] Federal University of Rio Grande do Sul, 2006.

GONZALEZ, J. M. International Soil and Water Conservation Research Runoff and losses of nutrients and herbicides under longterm conservation practices (no-till and crop rotation ) in the $U$ . S . Midwest: Avariable intensity simulated rainfall approach. International Soil and Water Conservation Research, v.6, n.4, p.265-274, 2018. Available from: <https://doi.org/10.1016/j. iswcr.2018.07.005>. Accessed: Feb. 28, 2020.

HOLTHUSEN, D. et al. Soil porosity, permeability and static and dynamic strength parameters under native forest/grassland compared to no-tillage cropping. Soil and Tillage Research, v.177, n. June 2017, p.113-124, 2018. Available from: $<10.1016 / j$. still.2017.12.003>. Accessed: Feb. 28, 2020.

IUSS WORKING GROUP WRB. World reference base for soil resources 2014, update 2015 International soil classification system for naming soils and creating legends for soil maps. World Soil Resources Reports No. 106. FAO, Rome: [s.n.].

LONDERO, A. L. et al. Impact of broad-based terraces on water and sediment losses in no-till (paired zero-order) catchments in southern Brazil. Journal of Soils and Sediments, v.18, n.3, p.1159-1175, 17 mar. 2018. Available from: <10.1007/s11368017-1894-y>. Accessed: Feb. 28, 2020.

MARTÍNEZ-CARRERAS, $\mathrm{N}$. et al. The Influence of Sediment Sources and Hydrologic Events on the Nutrient and Metal Content of Fine-Grained Sediments (Attert River Basin, Luxembourg). Water, Air, \& Soil Pollution, v.223, n.9, p.56855705, 20 nov. 2012. Available from: $<10.1007 / \mathrm{s} 11270-012-1307-1>$. Accessed: Feb. 28, 2020.

MURPHY, J.; RILEY, J. P. A modified single solution method for the determination of phosphate in natural waters. Analytica Chimica 
Acta, 1962. Available from: $<10.1016 /$ S0003-2670(00)88444-5>. Accessed: Feb. 28, 2020.

NIE, X. et al. Soil Organic Carbon Loss and Selective Transportation under Field Simulated Rainfall Events. PLoS ONE, v.9, n.8, p.e105927, 28 ago. 2014. Available from: $<$ https://doi.org/10.1371/journal.pone.0105927>. Accessed: Feb. 28, 2020.

OBREGÓN, G.; MARENGO, J. A. Mudanças Climáticas Globais e seus Efeitos sobre a Biodiversidade: Caracterização do Clima no Século XX no Brasil: Tendências de Chuvas e Temperaturas Médias e Extremas. 2007.

QUINTON, J. N. et al. The impact of agricultural soil erosion on biogeochemical cycling. Nature Geoscience, v.3, n.5, p.311-314, 2010. Available from: <10.1038/ngeo838>. Accessed: Feb. 28, 2020.

RAMOS, M. C.; MARTÍNEZ-CASASNOVAS, J. A. Erosion rates and nutrient losses affected by composted cattle manure application in vineyard soils of NE Spain. Catena, 2006a. Available from: <10.1016/j.catena.2006.04.004>. Accessed: Feb. 28, 2020.

RAMOS, M. C.; MARTÍNEZ-CASASNOVAS, J. A. Nutrient losses by runoff in vineyards of the Mediterranean Alt Penedès region (NE Spain). Agriculture, Ecosystems and Environment, v.113, n.1-4, p.356-363, 2006b. Available from: $<10.1016 /$ j.agee.2005.10.009>. Accessed: Feb. 28, 2020.

REICHERT, J. M. et al. Reference bulk density and critical degreeof-compactness for no-till crop production in subtropical highly weathered soils. Soil and Tillage Research, v.102, n.2, p.242254, mar. 2009. Available from: <10.1016/j.still.2008.07.002>. Accessed: Feb. 28, 2020.

SARKAR, R. et al. Catena An insight into the runoff generation processes in wet sub-tropics: Field evidences from a vegetated hillslope plot. Catena, v.128, p.31-43, 2015. Available from: $<10.1016 /$ j.catena.2015.01.006>. Accessed: Feb. 28, 2020.

SOLO, CQFS-RS/SC - Comissão de Química e Fertilidade do Solo - RS/SC. Manual de calagem e adubação para os Estados do Rio Grande do Sul e de Santa Catarina. $11^{\mathrm{a}}$ ed. SociedadeBrasileira deCiência doSolo-Núcleo Regional Sul. [s.1.], 376p., 2016.

TANG, X. et al. Science of the Total Environment In fl uence of turbid fl ood water release on sediment deposition and phosphorus distribution in the bed sediment of the Three Gorges. Science of the Total Environment, v.657, p.36-45, 2019. Available from: $<$ 10.1016/j.scitotenv.2018.12.011>. Accessed: Feb. 28, 2020.

TEDESCO, M. J. et al. Análises de solo, plantas e outros materiais. [s.l: s.n.].

TIWARI, K. R. et al. Runoff and soil loss responses to rainfall, land use, terracing and management practices in the Middle Mountains of Nepal. Acta Agriculturae Scandinavica, Section B - Plant Soil Science, v.59, n.3, p.197-207, maio 2009. Available from: <10.1080/09064710802006021>. Accessed: Feb. 28, 2020.

VOGELMANN, E. S. et al. Can occurrence of soil hydrophobicity promote the increase of aggregates stability? Catena, v.110, p.24-31, 2013. Available from: <10.1016/j.catena.2013.06.009>. Accessed: Feb. 28, 2020.

WINGEYER, A. et al. Soil Quality Impacts of Current South American Agricultural Practices. Sustainability, v.7, n.2, p.22132242, 17 fev. 2015. Available from: <10.3390/su7022213>. Accessed: Feb. 28, 2020.

ZHANG, P. et al. Uncertainty of SWAT model at different DEM resolutions in a large mountainous watershed. Water Research, v.53, p.132-144, abr. 2014. Available from: $<10.1016 / j$. watres.2014.01.018>. Accessed: Feb. 28, 2020. 